\title{
SEDIMENTATION RATES IN CACHOEIRA DE CIMA RESERVOIR, MOGI GUAÇU MUNICIPALITY, SP, BRAZIL
}

\section{TAXA DE SEDIMENTAÇÃO NA REPRESA CACHOEIRA DE CIMA, MUNICÍPIO DE MOGI GUAÇU, SP, BRASIL}

\section{André Gustavo Mazzini Bufon ${ }^{1 *}$; Claudio Luiz Bock²; Sâmia Maria Tauk-Tornisielo ${ }^{1}$; José Sávio Colares de Meloº ${ }^{2}$ Osmar Angelo Cantelmo ${ }^{2}$; Ana Olívia Fernandes ${ }^{3}$, Aline Lucas Muller $^{3}$}

${ }^{1}$ Centro de Estudos Ambientais, Universidade Estadual Paulista - UNESP, Campus de Rio Claro, avenida 24-A, 1515, Bela Vista, CEP 13506-900, Rio Claro(SP), Brasil.

${ }^{2}$ Centro de Nacional de Pesquisa e Conservação de Peixes Continentais CEPTA/ICMBio, Rod. SP 201, km 6,5, Caixa Postal 64, CEP 13630-970, Pirassununga (SP), Brasil.

${ }^{3}$ Faculdade Municipal Prefeito Franco Montoro - FMPFM, Estrada Luciano Gonçalves Ferreira, 2350, Cachoeira de Cima, Caixa Postal 293, CEP 13843-971,

Mogi Guaçu (SP), Brasil.

*Author for correspondence. E-mail: abufon@bol.com.br

\begin{abstract}
The aim of this study was to analyze the sedimentation rates of suspended material and to estimate the lifetime of the Cachoeira de Cima reservoir, in Mogi Guaçu municipality, Sao Paulo State. Sedimentation chambers were used to collect samples of suspended material. Sedimentation rates for total suspended material (TSM) ranged between 0.27 and $40.70 \mathrm{mg} \mathrm{cm}^{-2} \mathrm{~d}$, for inorganic suspended material (ISM), between 0.05 and $34.19 \mathrm{mg} \mathrm{cm}^{-2} \mathrm{~d}$, and organic suspended material (OSM), between 0.18 and $6.52 \mathrm{mg} \mathrm{cm}^{-2} \mathrm{~d}$. Sedimentation rates of TMS, IMS and OMS at the Cachoeira de Cima reservoir are higher in the rainy season. The lifetime of the reservoir is estimated at 75 years.
\end{abstract}

Keywords: Organic Matter. Inorganic Matter. Reservoirs. Useful Life. Sediment. Sedimentation Rate.

\section{RESUMO}

O objetivo deste trabalho foi analisar as taxas de sedimentação de material em suspensão e estimar o tempo de vida útil da represa Cachoeira de Cima, no município de Mogi Guaçu, Estado de São Paulo. Foram utilizadas câmaras de sedimentação, para coleta de amostras de material em suspensão. As taxas de sedimentação para material em suspensão total (TSM) variaram entre 0,27 e 
40,70 $\mathrm{mg} \mathrm{cm}^{-2} \mathrm{~d}$, para material em suspensão inorgânico (ISM), entre 0,05 e 34,19 $\mathrm{mg} \mathrm{cm}^{-2} \mathrm{~d}$, e para material em suspensão orgânico (OSM), entre 0,18 e $6,52 \mathrm{mg} \mathrm{cm}^{-2} \mathrm{~d}$. As taxas de sedimentação de TSM, ISM e OSM na represa Cachoeira de Cima são maiores no período chuvoso. O tempo de vida útil do reservatório é estimado em 75 anos.

Palavras-chave: Matéria Orgânica. Matéria Inorgânica. Reservatórios. Vida Útil. Sedimento. Taxa de Sedimentação.

\section{INTRODUCTION}

When studying the environmental sustainability of Cachoeira de Cima reservoir, one of the great expectations is the conservation and rational use of the Mogi Guaçu river, state of Sao Paulo, regarding water quality in order to meet the multiple uses of this resource. For this to happen it is necessary to know the chemical, physical and biological processes that interact within this ecosystem, generating information through in-depth studies and researches, for the subsequent implementation of more suitable management plans.

Reservoirs have major importance because of its multiple uses such as electricity production, irrigation, fish farming, and water for human consumption, recreation and navigation. As a result, many problems can be seen such as the disposal of industrial and domestic waste, sugar cane effluents, among others (LEITE, 1998; VIEIRA et al., 2002), and particularly in the Cachoeira de Cima reservoir, sand mining, with detachment of large amounts of sediment.

Sediments can be defined as a collection of minerals and organic particles found at the bottom, forming an important component of the aquatic ecosystem. The determination of sediment quality is of primary importance in environmental studies, since only water analysis does not evaluate environmental risks that can appear over time (CUNHA et al., 2006).

The deposition of sediments can occur close or distant from the source of erosion. The material can be deposited in local plans, channels, floodplains, reservoirs, deltas, estuaries or oceans. The sediments can cause damage, depending on the quantity, quality and deposition site. In reservoirs, the process of sedimentation can reduce the lifetime of the system, causing great economic losses and environmental problems.

According to Thornton (1990), transport and deposition of sediments are the dominant processes in reservoirs, significantly influencing the mechanisms and processes of the system. Furthermore, sediment also functions as a major catalyst carrier of pesticides, organic waste, nutrients and pathogens.

The presence of nutrients, specially nitrogen and phosphorus in water and sediments, is related to the addition of inorganic fertilizer used in agricultural activities and also directly related to plant and animal biomass in various states of decomposition, resulting from the chemical and biological degradation as well as synthetic activity of microorganisms (COTA et al., 2007).

The phenomenon of eutrophication in aquatic environments is characterized by a high amount of nutrients, especially phosphates and nitrates. It is a result of water pollution by ejection of fertilizers, detergents and sewage without pretreatment, increasing the amount of minerals, followed by algal blooms in the surface of water bodies (AMABIS and MARTHO, 2003). The conditions of eutrophication in open aquatic environments can reduce species diversity and destabilize chemical, physical and biological relations of the systems.

The objective of this study was to analyze the concentrations of suspended material and estimate the lifetime of the Cachoeira de Cima reservoir in the municipality of Mogi Guaçu, Sao Paulo State. 


\section{MATERIAL AND METHODS}

The studies were conducted at the Cachoeira de Cima reservoir in the Mogi Guaçu river, with the contribution of the Do Peixe river, which has its mouth very close, upstream of the reservoir, in the Mogi Guaçu municipality, Sao Paulo State.

The Cachoeira de Cima reservoir serves the Mogi Guaçu PCH (Small Hydroelectric Plant), which was built in 1999 and has an area of $5.73 \mathrm{~km}^{2}$, a volume of $32.8910^{6} \mathrm{~m}^{3}$ and an average depth of $5.76 \mathrm{~m}$ (AES TIETE, 2008). Nine georeferenced sampling points were established in the reservoir (Table 1).

Samples of suspended material deposited in sedimentation chambers were collected in the months of June, July and August 2008 (dry season) and December 2008, January and February 2009 (rainy season), making a total of 6 samplings trips. The analyses were performed at the FMPFM Chemistry Laboratory, located at Rua do Estudante, s/n, Cachoeira de Cima, Mogi Guaçu city, Sao Paulo State.

In each sampling point a set of 4 sedimentation chambers were installed, built with PVC pipes of $10 \mathrm{~cm}$ diameter by $30 \mathrm{~cm}$ long, which represents a ratio length / diameter of 3:1 (MARICATO, 1994). The chambers were arranged vertically in the water column, distant $50 \mathrm{~cm}$ from the bottom sediment.

Table 1 - Description of the sampling points, depth and coordinates in the Cachoeira de Cima reservoir, Mogi Guaçu river, Sao Paulo State, Brazil.

\begin{tabular}{|c|c|c|c|}
\hline Points & Description & Depth (m) & Coordinates \\
\hline \multirow[t]{2}{*}{1} & \multirow{2}{*}{$\begin{array}{l}\text { Downstream from the entry point of } \\
\text { water in the reservoir }\end{array}$} & \multirow{2}{*}{7.0} & $22^{\circ} 22^{\prime} 50,04^{\prime \prime} \mathrm{S}$ \\
\hline & & & $46^{\circ} 52^{\prime} 48,97^{\prime \prime} \mathrm{W}$ \\
\hline \multirow[t]{2}{*}{2} & \multirow{2}{*}{$\begin{array}{l}\text { Next to the mouth of a creek with a } \\
\text { strong influence of agriculture } \\
\text { (sugarcane, maize, beans) - right bank }\end{array}$} & \multirow[b]{2}{*}{3.5} & \\
\hline & & & $46^{\circ} 53,09,52^{\prime \prime} \mathrm{W}$ \\
\hline \multirow{2}{*}{3} & \multirow{2}{*}{ Central point of reservoir } & \multirow{2}{*}{3.5} & $22^{\circ} 22^{\prime} 39,18^{\prime \prime} \mathrm{S}$ \\
\hline & & & $46^{\circ} 53^{\prime} 18,59^{\prime \prime} \mathrm{W}$ \\
\hline \multirow[t]{2}{*}{4} & \multirow{2}{*}{$\begin{array}{l}\text { Small tributary, right side of the } \\
\text { reservoir - fishermen facilities }\end{array}$} & \multirow{2}{*}{4.0} & $22^{\circ} 22^{\prime} 31,37^{\prime \prime} \mathrm{S}$ \\
\hline & & & $46^{\circ} 53^{\prime} 36,60^{\prime \prime} \mathrm{W}$ \\
\hline \multirow[t]{2}{*}{5} & \multirow{2}{*}{$\begin{array}{l}\text { In front of the sand harbor } \\
\text { interdicted at the time }\end{array}$} & \multirow{2}{*}{13.0} & $22^{\circ} 22^{\prime} 40,89^{\prime} \mathrm{S}$ \\
\hline & & & $46^{\circ} 53^{\prime} 44,54^{\prime \prime} \mathrm{W}$ \\
\hline \multirow[t]{2}{*}{6} & \multirow{2}{*}{$\begin{array}{l}\text { Central point of a narrowed channel } \\
\text { between exposed rocks }\end{array}$} & \multirow{2}{*}{12.0} & $22^{\circ} 22^{\prime} 52,80^{\prime \prime} \mathrm{S}$ \\
\hline & & & $46^{\circ} 53 ' 51,71 " \mathrm{~W}$ \\
\hline \multirow[t]{2}{*}{7} & \multirow{2}{*}{ Left bank in front of the pasture area } & \multirow{2}{*}{2.5} & $22^{\circ} 22^{\prime} 53,14^{\prime \prime} \mathrm{S}$ \\
\hline & & & $46^{\circ} 53^{\prime} 59,45^{\prime \prime} \mathrm{W}$ \\
\hline \multirow[t]{2}{*}{8} & \multirow{2}{*}{$\begin{array}{l}\text { Next to AES Tiete Hydroelectric } \\
\text { Plant - in front of the dam's } \\
\text { embankment }\end{array}$} & \multirow[b]{2}{*}{3.0} & $22^{\circ} 22^{\prime} 49,33^{\prime \prime} \mathrm{S}$ \\
\hline & & & $46^{\circ} 54^{\prime} 03,11^{\prime \prime} \mathrm{W}$ \\
\hline \multirow[t]{2}{*}{9} & \multirow{2}{*}{$\begin{array}{l}\text { Next to the hydroelectric plant - in } \\
\text { front of AES Tiete's office, right } \\
\text { bank }\end{array}$} & \multirow{2}{*}{1.5} & $22^{\circ} 22^{\prime} 48,53^{\prime \prime} \mathrm{S}$ \\
\hline & & & $46^{\circ} 53^{\prime} 59,53^{\prime \prime} \mathrm{W}$ \\
\hline
\end{tabular}


The chambers were filled with distilled water and then placed at the established depths, being tied to floats and anchored at each sampling point, thus allowing evaluation of the spatial difference in sedimentation of suspended material.

The exposure time of the chambers was 24 hours (daily cycle) as described in Leite (1998), which is a sufficient time for the accumulation of sediments in the collectors. After this period, the contents of the chamber were collected, homogenized and placed in gallons for transportation to the laboratory where the analysis was performed gravimetrically (WETZEL and LIKENS, 1979).

Concentrations of Total Suspended Material (TSM), Inorganic Suspended Material (ISM) and Organic Suspended Material (OSM) were determined in samples of known volume retained in fiber-glass filters, previously calcined and with a known mass (P1). The filters containing retained material from the samples were oven dried at $60^{\circ} \mathrm{C}$ for $24 \mathrm{~h}$, cooled and weighed (P2). They were then calcined in a muffle furnace at $480^{\circ} \mathrm{C}$ for $60 \mathrm{~min}$., cooled in a desiccator and weighed (P3).

The concentrations were obtained from the equations:

$$
\operatorname{TSM}\left(\mathrm{mg} \mathrm{L}^{-1}\right)=(\mathrm{P} 2-\mathrm{P} 1) / \mathrm{V}
$$

where TSM is the total suspended material $\left(\mathrm{mg} \mathrm{L}^{-1}\right), \mathrm{P} 2$ is the weight of the dried material retained by the filter (mg), P1 is the initial weight of filter $(\mathrm{mg})$ and $\mathrm{V}$ is the volume of the sample used during filtration (1);

$$
\operatorname{ISM}\left(\mathrm{mg} \mathrm{L}^{-1}\right)=(\mathrm{P} 3-\mathrm{P} 1) / \mathrm{V}
$$

where ISM is the inorganic suspended material $\left(\mathrm{mg} \mathrm{L}^{-1}\right)$ and P3 is the weight of the filter after burning off the organic matter in a muffle (mg).

$$
\text { OSM }=\text { TSM }- \text { ISM }
$$

where OSM is the organic suspension material in $\left(\mathrm{mg} \mathrm{L}^{-1}\right)$.

The sedimentation rates were calculated as the material accumulated in the chambers during the 24 hour period and expressed in $\mathrm{mg} \mathrm{cm}^{-2} \mathrm{~d}$ by the equation:

$$
\mathrm{ST}=\left(\begin{array}{ll}
\mathrm{Vc} & \mathrm{C}
\end{array}\right) /\left(\begin{array}{ll}
\mathrm{Ac} & \mathrm{t}
\end{array}\right)
$$

where ST is the sedimentation rate $\left(\mathrm{mg} \mathrm{cm}^{-2} \mathrm{~d}\right), \mathrm{Vc}$ is the volume of each chamber $(\mathrm{L}), \mathrm{C}$ is the average concentration of sediment $\left(\mathrm{mg} \mathrm{L}^{-1}\right)$, Ac is the area of the base of each chamber $\left(\mathrm{cm}^{2}\right)$ and $\mathrm{t}$ is the exposure time of the sedimentation chamber in days $(d)$.

To enable statistical analysis, the results were grouped into areas: Area 1 - points 1, 2 and 3; Area 2 - points 4, 5 and 6; Area 3 - points 7, 8 and 9.

To estimate the lifetime of the reservoir, it used information obtained from the 9 sampling points. The siltation time was established by calculating the mean values of all total suspended material $\left(\mathrm{mg} \mathrm{L}^{-1}\right)$, which were correspondent with the months and sampling points in the reservoir, and the apparent specific weight of the dry material.

Total suspended material values, which corresponds to the amount of sediment retained in the filter, was corrected to the mean volume of the sedimentation chambers, expressed in units of volume and time (number of days of exposure). To calculate the apparent specific weight of the dried material it was used a volumetric flask of $100 \mathrm{ml}$ of known weight, which had been filled with 
the air dried material (compacting it by tapping until it reached the meniscus) and then the set was weighed.

The sedimentation time (T), which estimates the lifetime of the reservoir, was obtained by the equation:

$$
\mathrm{T}=\mathrm{V} \quad \mathrm{d} / \mathrm{P}
$$

where $\mathrm{T}$ is the time of sedimentation (years), $\mathrm{V}$ is the reservoir volume $\left(\mathrm{m}^{3}\right), \mathrm{d}$ is the apparent specific gravity $\left(\mathrm{t} \mathrm{m}^{-3}\right)$ and $\mathrm{P}$ is the mass of suspended matter accumulated in the reservoir per year $\left(\mathrm{t} \mathrm{y}^{-1}\right)$.

The apparent specific gravity (d) of the dried material is given by the equation:

$$
\mathrm{d}=(\mathrm{p}-\mathrm{q}) / \mathrm{v}
$$

where $\mathrm{v}$ is the volume of the balloon, $\mathrm{q}$ is the weight of the flask and $\mathrm{p}$ is the weight of balloon + the weight of the air dried material.

The mass of suspended matter $(\mathrm{P})$ was obtained by the equation:

$$
\mathrm{P}=\mathrm{V} \quad \mathrm{p}^{\prime}
$$

where $\mathrm{V}$ is the reservoir volume $\left(\mathrm{m}^{3}\right)$ and $\mathrm{p}^{\prime}$ is the annual rate of sedimentation $\left(\mathrm{t} \mathrm{m}^{-3} \mathrm{y}\right)$, obtained by the equation:

$$
\mathrm{p}^{\prime}=(\mathrm{S} / \mathrm{L} / \mathrm{N}) \mathrm{C} \mathrm{A}
$$

where $\mathrm{S}$ is the total suspended matter, $\mathrm{L}$ is the number of sampling points, $\mathrm{N}$ is the number of sampling trips, $\mathrm{C}$ is the correction constant for liters and $\mathrm{A}$ is the number of days considered (1 day).

The data of suspended solids (total, inorganic and organic) were subjected to statistical analysis using the Mann-Whitney one-sided Test with a significance level $\alpha=0.05$.

\section{RESULTS AND DISCUSSION}

In the Cachoeira de Cima reservoir, the highest value for the spatiotemporal sedimentation rate of Total Suspended Material (TSM) was $40.70 \mathrm{mg} \mathrm{cm}^{-2} \mathrm{~d}$, in point 1, during the rainy season (February 2009), and lowest, $0.27 \mathrm{mg} \mathrm{cm}^{-2} \mathrm{~d}$, in point 9, during the dry season (August 2008) (Table 2).

In a study by Leite (1998) in the Salto Grande Reservoir (SP), sedimentation rate of TSM at the reservoir presented values of $2.23 \mathrm{mg} \mathrm{cm}^{-2} \mathrm{~d}$ during the rainy season and $1.20 \mathrm{mg} \mathrm{cm}^{-2} \mathrm{~d}$ during the dry season.

The TSM sedimentation rate can vary within the rainy season. Additionally, lakes from tropical climate, where its waters invade the surrounding soil, can receive a large input of organic and inorganic materials. In the dry season, the deposition of fine particles of silt and clay is higher than in the rainy season, due to low turbulence in the water body (BUFON, 2002).

According to Bufon $(2002,2006)$, in studies performed in a reservoir called Represa Velha, with $5 \mathrm{ha}$, in the municipality of Pirassununga/SP, the highest value obtained for the TSM 
sedimentation rate, including allochthonous inorganic matter, was in the rainy/hot season at the entrance of the Barrinha stream inside the reservoir; these results show that the deposition of material in the delta of the reservoir is higher due to the size of sand grains.

For the samples made between the years 2008 and 2009, the value of spatiotemporal sedimentation rates of Inorganic Suspended Material in (ISM) analyzed in the Cachoeira de Cima reservoir, in the Mogi Guaçu river, as indicated in Table 3, showed the lowest value in the dry season, in point 9, in August 2008, of $0.05 \mathrm{mg} \mathrm{cm}^{-2} \mathrm{~d}$. In the rainy season, the highest value obtained was $34.19 \mathrm{mg} \mathrm{cm}^{-2} \mathrm{~d}$ in point 1 , in February 2009.

The ISM is composed predominantly by silica, clay and calcium compounds, iron and manganese, among others. In Brazil, this type of material is found mostly in lagoons and reservoirs (ESTEVES, 1988).

Table 2 - Spatial and temporal variation of the values of sedimentation rates of Total Suspended Material (TSM) $\left(\mathrm{mg} \mathrm{cm}^{-2} \mathrm{~d}\right)$, in Cachoeira de Cima reservoir, Mogi Guaçu river, in the years 2008 and 2009.

\begin{tabular}{rrrrrrr}
\hline \multirow{2}{*}{ Points } & & $\mathbf{2 0 0 8}$ & & \multicolumn{3}{c}{$\mathbf{2 0 0 9}$} \\
\cline { 2 - 7 } & June & July & August & December & January & February \\
\hline 1 & 1.48 & 8.57 & 4.46 & 28.19 & 37.46 & 40.70 \\
2 & 18.29 & 1.84 & 1.15 & 1.69 & 3.68 & 1.94 \\
3 & 2.58 & 0.30 & 1.57 & 7.61 & 18.41 & 16.44 \\
4 & 1.11 & 0.53 & 0.66 & 1.21 & 6.10 & 1.25 \\
5 & 8.36 & 3.51 & 2.78 & 6.80 & 25.38 & 13.97 \\
6 & 8.61 & 3.20 & 3.32 & 6.07 & 21.78 & 14.30 \\
7 & 1.78 & 0.43 & 0.52 & 7.09 & 11.09 & 3.09 \\
8 & 1.70 & 0.74 & 0.76 & 2.38 & 9.33 & 3.95 \\
9 & 1.47 & 0.31 & 0.27 & 2.94 & 7.57 & 4.82 \\
\hline
\end{tabular}

Table 3 - Spatial and temporal variation of the values of sedimentation rates of Inorganic Suspended Material (ISM) $\left(\mathrm{mg} \mathrm{cm}^{-2} \mathrm{~d}\right)$, at Cachoeira de Cima reservoir in the Mogi Guaçu river, in the years 2008 and 2009.

\begin{tabular}{lrrrrrr}
\hline \multirow{2}{*}{ Points } & \multicolumn{3}{c}{$\mathbf{2 0 0 8}$} & & & \multicolumn{2}{c}{2009} & \\
\cline { 2 - 7 } & June & July & August & December & January & February \\
\hline 1 & 1.00 & 6.75 & 3.33 & 23.72 & 31.31 & 34.19 \\
2 & 15.06 & 1.25 & 0.46 & 0.90 & 2.68 & 1.43 \\
3 & 2.13 & 0.12 & 0.81 & 5.96 & 15.70 & 13.05 \\
4 & 0.72 & 0.19 & 0.26 & 0.56 & 4.18 & 0.80 \\
5 & 6.53 & 2.59 & 1.83 & 5.33 & 20.71 & 10.09 \\
6 & 6.72 & 2.19 & 2.27 & 4.83 & 19.02 & 10.94 \\
7 & 1.25 & 0.10 & 0.16 & 5.39 & 8.44 & 2.35 \\
8 & 1.17 & 0.38 & 0.37 & 1.54 & 7.28 & 2.96 \\
9 & 0.99 & 0.12 & 0.05 & 1.97 & 6.11 & 3.58 \\
\hline
\end{tabular}


The spatiotemporal values of sedimentation rates of organic suspended material (OSM) is presented in Table 4, where it is observed that the highest value was recorded in the rainy season, $6.52 \mathrm{mg} \mathrm{cm}^{-2} \mathrm{~d}$ in February 2009, and the lowest, $0.18 \mathrm{mg} \mathrm{cm}^{-2} \mathrm{~d}$, in point 3, in July 2008.

The particulate organic matter in lakes may result from allochthonous sources (organic fertilizer and animal feed) or native (natural organic material, plant and animal), including living and non-living organisms, free and floating on the water, which participate in the trophic system (BUFON, 2002).

Table 4 - Spatiotemporal variation of the sedimentation rate values of Organic Suspended Material (OSM) $\left(\mathrm{mg} \mathrm{cm}{ }^{-2} \mathrm{~d}\right)$, in the Cachoeira de Cima reservoir, in Mogi Guaçu river, in the years 2008 and 2009.

\begin{tabular}{lcccccc}
\hline \multirow{2}{*}{ Points } & \multicolumn{3}{c}{$\mathbf{2 0 0 8}$} & & \multicolumn{3}{c}{$\mathbf{2 0 0 9}$} \\
\cline { 2 - 7 } & June & July & August & December & January & February \\
\hline 1 & 0.48 & 1.82 & 1.13 & 4.47 & 6.16 & 6.52 \\
2 & 3.23 & 0.59 & 0.69 & 0.80 & 1.00 & 0.51 \\
3 & 0.46 & 0.18 & 0.76 & 1.65 & 2.71 & 3.39 \\
4 & 0.40 & 0.34 & 0.41 & 0.65 & 1.92 & 0.45 \\
5 & 1.83 & 0.92 & 0.94 & 1.47 & 4.67 & 3.89 \\
6 & 1.89 & 1.01 & 1.06 & 1.24 & 2.76 & 3.36 \\
7 & 0.53 & 0.34 & 0.36 & 1.70 & 2.65 & 0.74 \\
8 & 0.53 & 0.36 & 0.39 & 0.84 & 2.05 & 0.99 \\
9 & 0.48 & 0.20 & 0.23 & 0.97 & 1.45 & 1.23 \\
\hline
\end{tabular}

The high values obtained for sedimentation rates of TSM, ISM and OSM are probably influenced by sand extraction in the bed and banks of Do Peixe and Mogi-Guaçu rivers, lack of riparian vegetation along the riverbanks and land use mainly for sugarcane agriculture, which do not respect the law imposed limits of preservation of riparian forests, and especially the lack of soil conservation and preservation of the legal reserve areas.

Sedimentation rates of TSM, ISM and OSM were significantly higher in the rainy season (P $<0.05)$. This probably occurs due to sediment entrainment from the contributing river basin during rainfalls. In the dry season, there was no significant difference between the percentage of ISM and OSM in Area 5 ( $\mathrm{P}>0.05$ ), probably due to contributions of organic matter originating from livestock activities and seedling nurseries around in this area. 

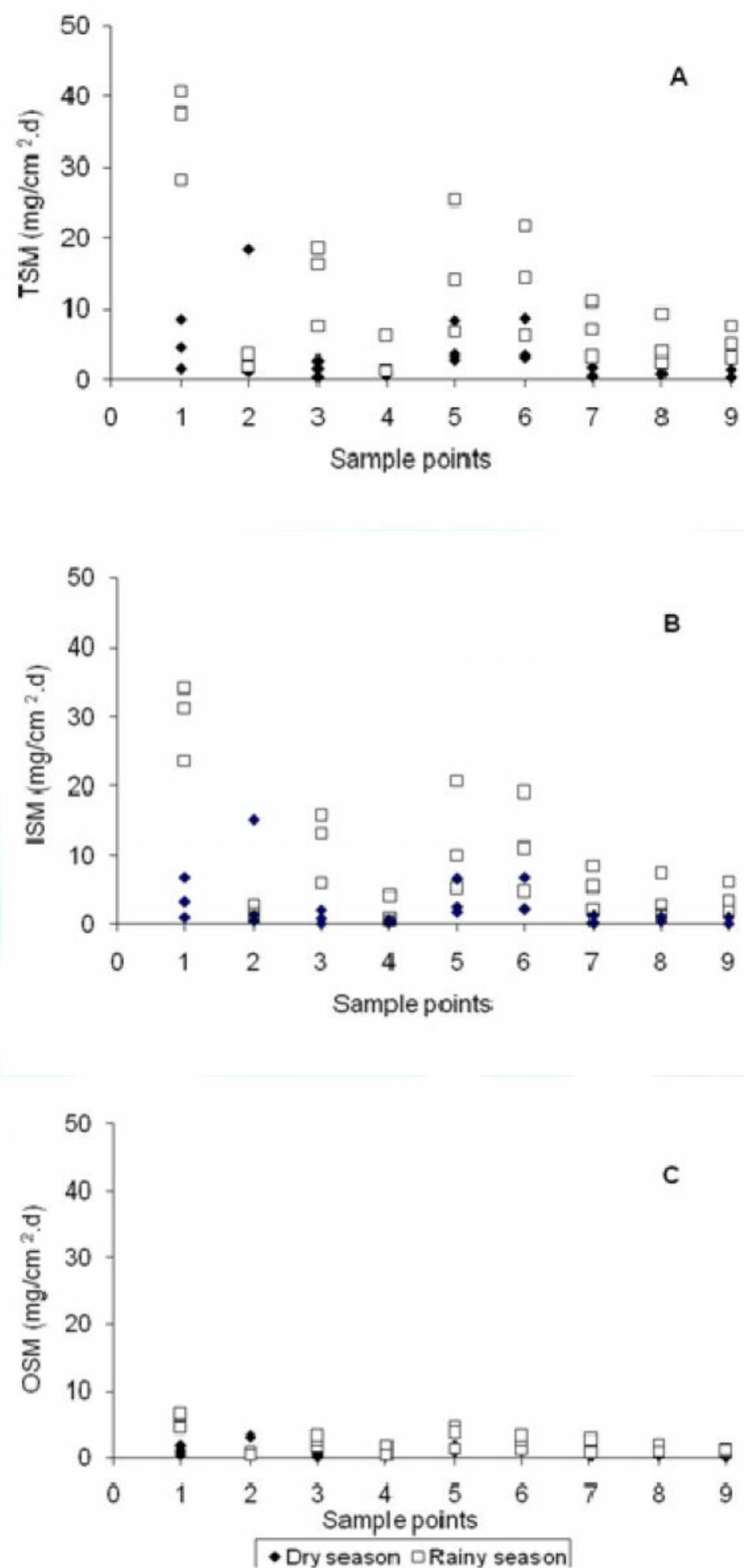

Figure 1. Spatial distribution and seasonal rates of sedimentation of total suspended matter - TSM - (A), inorganic - ISM - (B) and organic - OSM - (C) at the Cachoeira de Cima reservoir, in Mogi Guaçu river, during the dry season of 2008 and the rainy season of 2009.

The lifetime (T) of Cachoeira de Cima reservoir, in the Mogi-Guaçu river, was estimated based on data from Table 5 . 
Table 5 - Variables and values for calculating the lifetime of the Cachoeira de Cima reservoir.

\begin{tabular}{clc}
\hline Variable & \multicolumn{1}{c}{ Description } & Value \\
\hline $\mathrm{S}$ & total suspended solids $\left(\mathrm{mg} \mathrm{L}^{-1}\right)$ & 951.93 \\
$\mathrm{~L}$ & number of sample points & 9 \\
$\mathrm{~N}$ & number of sampling trips & 6 \\
$\mathrm{C}$ & constant correction to liter & 6.67 \\
$\mathrm{~A}$ & number of days taken & 183 \\
$\mathrm{p}$ & annual sedimentation rate $\left(\mathrm{t} \mathrm{m}^{-3} \mathrm{y}\right)$ & 0.021517395 \\
$\mathrm{P}$ & mass of sediment accumulated in the reservoir per year $\left(\mathrm{t}^{-1}\right)$ & $707,707.13$ \\
$\mathrm{~V}$ & Reservoir volume $\left(\mathrm{m}^{3}\right)$ & $32,890,000$ \\
$\mathrm{~d}$ & apparent specific gravity $\left(\mathrm{t} \mathrm{m}^{-3}\right)$ & 1.61 \\
\hline
\end{tabular}

Thus, as $\mathrm{T}$ is equal to the volume of the reservoir times the apparent specific weight divided by the mass of accumulated sediment per year in the reservoir, then:

$\mathrm{T}=32,890,000 \mathrm{~m}^{3} 1.61 \mathrm{t} \mathrm{m}^{-3} / 707,707.13 \mathrm{t} \mathrm{y}^{-1}=74.82 \approx 75$ years

Therefore, the useful life estimated for the Cachoeira de Cima reservoir, in Mogi Guaçu river, was 75 years. To calculate the siltation time, it is expected to occur each year a deposit (P) of suspended matter in the reservoir. Bufon (2006), using the method of sedimentation chamber in the Represa Velha reservoir, found as a result a useful lifetime of 60 years, which is similar to the value obtained for the Cachoeira de Cima reservoir.

\section{CONCLUSIONS}

Sedimentation rates of Total, Inorganic and Organic Suspended Matter, in Cachoeira de Cima reservoir are higher in the rainy season. The useful lifetime of the Cachoeira de Cima reservoir is 75 years.

\section{ACKNOWLEDGMENTS}

The authors would like to thank Professor Luis Augusto Bresser Dores and trainees Maristela do Nascimento Rodrigues Perri and Valmir Percino Fazoli for their most valuable collaboration during sampling and processing, and MSc. Izabel Correa Boock de Garcia for her helpful comments and revision of the text in the English language.

\section{REFERENCES}

AES TIETÊ. Ficha Técnica: PCH Mogi-Guaçu. Disponível em:

<http://www.aestiete.com.br/artigo394.asp>. Acesso em: 18 nov. 2008. 
AMABIS, J.M.; MARTHO, G.R. Fundamentos da Biologia Moderna. 3 Ed. São Paulo: Editora Moderna, 2003. $550 \mathrm{p}$.

BUFON, A. G. M. Variação temporal e espacial da taxa de sedimentação e das características limnológicas na microbacia do córrego da Barrinha, no município de Pirassununga, SP. 2002. 180 f. Dissertação (Mestrado) - Centro de Estudos Ambientais, Universidade Estadual Paulista, Rio Claro, 2002.

BUFON, A. G. M. Estudo do assoreamento e sua relação com a vida útil do reservatório "represa Velha", CEPTA/IBAMA, Pirassununga/SP. 2006. 315 f. Tese (Doutorado) - Instituto de Geociências e Ciências Exatas, Universidade Estadual Paulista, Rio Claro, 2006.

COTTA, J.A.O.; SALAMI, F.H.; MARQUES, A.R.; REZENDE, M.O.O.; LANDGRAF, M.D. Validação do método para determinação de nitrogênio kjeldahl total. Revista Analytica, n. 26, p. 6875, 2007.

CUNHA, D. G. F.; CALIJURI; M. C.; MIWA, A. C. P. Estudo do sedimento do rio Jacupiranguinha, Vale do Ribeira, SP. In: REUNIÃO ANUAL DA SBPC, 58., Florianópolis. Anais... Florianópolis: SBPC, 2006. Disponível em:

<http://www.sbpcnet.org.br/livro/58ra/JNIC/RESUMOS/resumo_1265.html>. Acesso em: 15 dez. 2008.

ESTEVES, F. A. Fundamentos de limnologia. Rio de Janeiro: Interciência; FINEP, 1988. 575 p.

LEITE, M. A. Variação espacial e temporal da taxa de sedimentação no Reservatório de Salto Grande (SP) e sua influência sobre as características limnológicas do sistema. 1998. 170 f. Dissertação (Mestrado) - Escola de Engenharia de São Carlos, Universidade de São Paulo, São Carlos, 1998.

MARICATO, F. E. Caracterização físico-química e sedimentação nas regiões de desembocadura dos rios Paranapanema e Taquari, e no reservatório de Jurumirim (Alto Paranapanema-SP). 1994. 205 f. Dissertação (Mestrado) - Escola de Engenharia de São Carlos, Universidade de São Paulo, São Carlos, 1998.

THORNTON, K. W. Sedimentary process. In: THORNTON, K. W.; KIMMEL, B. L.; PAYNE, F. E. (Eds.) Reservoir limnology: ecological perspectives. New York: John Wiley Sons, 1990. p. 4369.

VIEIRA, M. S; FERREIRA, J. R.; CASTRO, P. M. G.; ROCHA, A. A. Aspectos da química da água e do sedimento do reservatório de Ibitinga, São Paulo - Brasil - $21^{\circ} 45^{\prime} \mathrm{S}$ e $48^{\circ} 50^{\prime} \mathrm{W}$.

Boletim do Instituto de Pesca, v. 28, n. 1, p. 77-91, 2002.

WETZEL, R. G.; LIKENS, G. E. Limnological analyses. Philadelphia: W.B. Saunder Company, 1979. $367 \mathrm{p}$. 